\title{
TEAMWORK RESEARCH METHOD BASED ON THE SYSTEM OF ORGANISATIONAL TERMS AND ONLINE MANAGEMENT TOOLS
}

\author{
Olaf Flak*
}

\begin{abstract}
Background. At present organisations have to respond more effectively to the dynamic and complex environments. Therefore team management has become more and more relevant as a method of increasing organisational efficiency. In order to ensure that a team can achieve the established goals, it is crucial to clarify managerial actions that govern effective team actions. Unfortunately, the present research methods create some methodological problems in the way to achieve clear answers to research questions in that field.
\end{abstract}

Research aims. The aim of the paper is (1) to present the original method of studying the activity of team managers and their teams based on the concept of organisational term, and (2) to present the results of the observation of the virtual team recorded by online management tools in TransistorsHead (online research platform).

Methodology. A review of literature led the author to design a system of organisational terms which include ontological and epistemological assumption of such research. The non-participating observation carried out with 41 students recorded by online management tools allows for verification of the appropriateness of the research method.

Key findings. The presented research method gives possibility of overcoming the domination of the study of organisational reality based on the situation at certain times and high influence of the researchers on the research results. It also allows making a step forward in pattern recognition in team management.

Keywords: team management, research method, system of organisational terms.

\footnotetext{
* University of Silesia in Katowice. E-mail: olaf.flak@us.edu.pl
} 


\section{INTRODUCTION}

Due to their ability to respond more effectively to dynamic and complex environments faced by the organisations today, work teams have become more and more relevant (Mathieu et al., 2008). This has enabled modern organisations to take the advantages of integrating all related activities by the means of teamwork (Shakshuki et al., 2003).

On the one hand, it is claimed that managerial work has a relatively stable nature. In some studies, we can find a surprising conclusion about the minimal effect of cultural change, empowerment and customer focus on the everyday work of managers (Watson, 1994, p. xii). On the other hand, managers do not have the luxury of standing back or outside of a situation in which they act. They have to take actions in the context of the situation. Managerial actions lead to consequences which managers are not able to foresee. Conversely, they need to be able to identify, articulate, and respond to unexpected contingencies (Segal, 2011, p. 472). The contradiction between these two approaches to managerial actions creates a gap for the scientific problem which can be described by several research questions:

- What are the managerial actions taken by team managers?

- When particular managerial actions are taken by team managers?

- How long do the managerial actions take?

- What are the common sequences of managerial actions taken by team managers?

Moreover, in order to ensure that a team can achieve the established goals, it is crucial to clarify managerial actions that govern effective team actions (Sinar \& Paese, 2016). From a practical point of view it can give a recognition of a level of similarity between managers on similar positions in the company, it can be used in the recruitment process and in the future it will let replace human managers with robots in certain types of managerial work.

However, from the methodological point of view answering these research questions is not an easy task. In the literature of management sciences, one comes across opinions that there is a great deal of methodological problems, such as the domination of the study of organisational reality based on the situation at certain times, leading to a static and momentary evaluation of the reality (Rokita, 2010, p. 258), too much influence of the subjectivity of the theorists on the theory 
(Sudoł, 2010), or the disproportionate nature of the whole scientific discipline, especially in terms of the methods of conducting research and interpreting its results (Sułkowski, 2004, p. 6).

The main contribution of this paper is a presentation of the original concept of research methodology used for team management research and the results of a study conducted on the basis of the system of organisational terms, which, as intended by the author, is to solve the aforementioned problems in management sciences.

Firstly, the paper aims at presenting selected key elements of the author's method of researching team managers' activities and activities of their teams based on the concept of organisational term. Secondly, the paper aims at presenting the results of the observation of the virtual team as exemplified by this team's activities, recorded by the research platform called TransistorsHead containing online management tools.

\section{RELATED WORK}

\section{Teamwork}

A team manager and team members are the warp and woof of the dynamic fabric of organisations (Sohmen, 2013). They cannot exist without each other activated by managerial actions as a constellation of specific objectives, resources, and processes (Sohmen, 2013).

In sociology the term used most often to describe the social activities is a social group. It means a collection of individuals in which the community of certain socially significant features is manifested in the building of community. This is accompanied by a variety of interactions, which within this collection of people are much more frequent and intense than with outsiders (Sztompka, 2005, p. 196). A group is also a collection of people who have a sense of common identity. There are structured interactions between them, based on a common set of expectations about the behaviour of their partners (Goodman, 1997, p. 54). Many types of groups can be found to which one may belong. They are types such as a group of origin, statistical group, referential group, alien one, etc. (Olechnicki \& Załęcki, 1998, pp. 73-75). From the point of view of management science, the most significant is membership in the social group. 
A group is defined as two or more individuals who cooperate and interact with each other in pursuit of a common goal. Cooperation means undertaking multi-stakeholder activities that create processes through a high degree of complexity (Stoner \& Wankel, 1994, p. 406). This changes a group into a team. The team is a group that has common goals, and its members are aware that their efforts are needed to achieve each of them. A group is a team when it considers itself unified and when it has its own teamwork ways.

The idea of teamwork is based on the synergy effect, which means that the effect of several closely collaborating individuals is greater than the sum of the effects produced by each of them in a situation if they were acting separately. For this reason, more and more companies are recognising the need for better integration of their employees.

In literature the view that the team is a specific group of people who meet the following conditions is also held (Antoszkiewicz, 1997, p. 198):

- it consists of two or more persons, but not too many, to ensure direct contact with another person of this collection,

- the intensity of interaction between them should exceed a certain minimum level,

- interactions should be interval, not in time,

- its members have a desire to cooperate,

- its members have a sense of belonging to this group.

Faced with the increasing role of network or virtual companies, the aspect of virtual team members in a geographic context is gaining major importance. At the same time the definitions of the team do not limit its existence to the physical presence of its members. It seems appropriate to use the term "virtual team" for calling such teams (Liao, 2017). It can therefore be considered that a dispersed group can be understood as a homogenous group that is deliberately created to accomplish specific objectives. It is characterised by the size that is required from the point of view of achieving these goals. It is also a mereological collection of people who do not have to be in direct physical proximity, but have a relationship of order. There are relationships between the members of the team. These relationships consist of simple actions and create processes (Iorioa \& Taylorb, 2015). 


\section{The system of organisational terms}

In order to build true knowledge on the team managerial actions, the concept of the system of organisational terms has been developed since 2007 (Flak, 2007). Firstly, the paradigm used in the system of organisational terms is a combination of neo-positivism, functionalism, and a system approach to an organisation (Holmwood, 2005). Secondly, the methodology of organisational research is a combination of qualitative and quantitative methods (Bryman, 2006). Thirdly, the philosophical foundation for the system of organisational terms was Ludwig Wittgenstein's philosophy and his "states of entities" (Brink \& Rewitzky, 2002).

The system of organisational terms consists of ontological and epistemological aspects and can be used as a foundation for managers' behaviour analysis (Flak, 2013b). Methodological solutions used in this study are derived from the earlier stage of conceptualisation (Flak, 2007, 2013b) and operationalisation (Flak, 2010). The most important part of the system of organisational terms are the concepts that represent the facts of the organisation when it functions. These concepts are called organisational terms (Flak, 2008). They form a complex in the sense of the whole, which means that the parts are contained in the whole, in which there is more than one internal relation (Krzyżanowski, 1985).

The system of organisational terms was based on the theory of facts, which distinguished two types of facts: events and things. Things (physical or mental ones, such as a timetable, motivation, an idea, a decision, an organisational structure, or an agenda of the meeting) are created by events (short or long processes: planning, motivating, creating, making, drawing, and preparing) (Flak, 2013b).

The characteristics of facts (reflected by concepts) in the system of organisational terms are grouped into dimensions and they are called measured values (Flak, 2010). It is not only about measurable features of objects that are resources (things) (Zieleniewski, 1965) or processes (events) (Grajewski, 2017). The characteristics of the facts cover the whole spectrum of parameters - measured values, both quantitative and qualitative.

In the concept of organisational terms, there are two types of organisation terms: primal and derivative. Primal terms reflect the facts of a "thing" type - in the language of management sciences these 
are resources. Derivative organisational terms reflect the events of the "incident" type - in the language of management sciences these are processes (Flak, 2007; Barney, 1991). By the same token, the system of organisational terms combines the resource approach and the process approach in management science. It combines processes which effect in resources. In pairs they create managerial actions.

There is an ontological assumption that every fact in the organisational reality can be represented by a specific term (Zalabardo, 2015), which in the system of organisational terms is called an organisational term. It is a symbolic object used as an element in a model of organisational reality (Rios, 2013). The organisational term is a close analogy to a physical quantity in the SI unit (length, mass, time, etc.). The organisational term can be changed quantitatively, qualitatively, mereologically, and substantially (Grygianiec, 2011). They are abstract objects which are used to represent the facts which appear in the organisational reality. Features of the organisational term come from its definition and causal relations or occurrence relations with other organisational terms (Backlund, 2000).

According to the system of organisational terms managerial actions can be organised by events and things. As it is shown in Figure 1, each event and thing have the label n.m ( $n$ and $m$ represent a number and a version of a thing, respectively). Event 1.1 causes thing 1.1 , which in turn releases event 2.1 that creates thing 2.1 . Thing 1.1 simultaneously starts event 3.1 which creates thing 3.1. Then, thing 3.1 generates

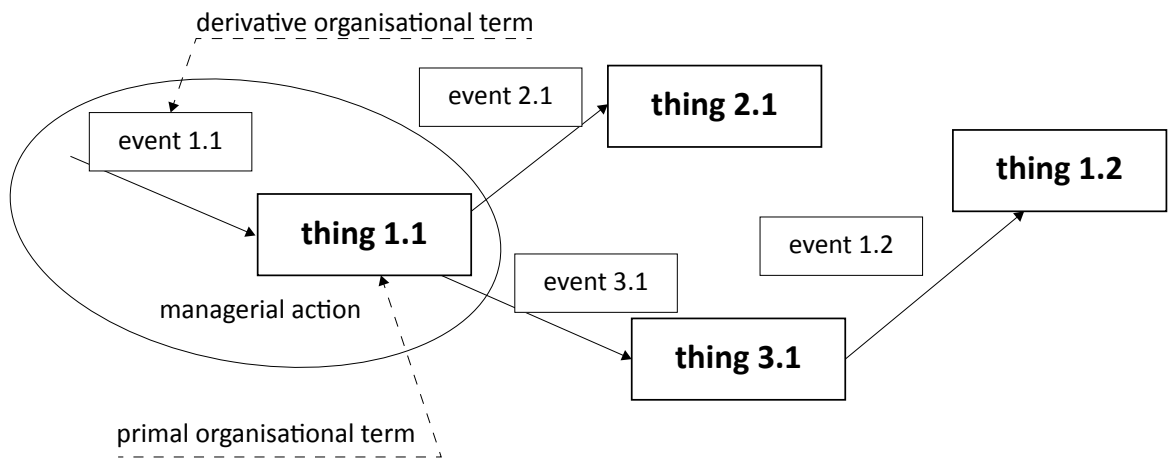

Figure 1. Fundamental structure of managerial actions

Source: own elaboration. 
a new version of the first event, i.e. event 1.2. In such way, a new version of the first thing is created, which is called thing 1.2. So, the managerial action structure consists of, e.g. event 1.1 and thing 1.1. They are a primal organisational term and a derivative organisational term, respectively.

Features of managerial actions are grouped in time, content and human relations domains. They show how much two managerial actions differ from one another or one managerial action differs from itself in the function of time. In the language of management sciences, it means how two pairs of a process and a resource differ from one another or how they differ from themselves in the function of time. Such an approach to ontology of a team manager's work allows for representing all their activities by standardised feature vectors with data grouped in time, content and human domains (Flak et al., 2017).

\section{RESEARCH METHOD}

The first aim of the paper is to present the selected key elements of the author's method of studying the activity of team managers and their teams based on the concept of organisational terms. In order to achieve this aim the following part of the paper describes the research method based on the system of organisational terms and online management tools as research tools.

So that data about managerial actions could gathered, one of the epistemological assumptions of the system of organisational terms is, that the main research method is an objective long-term observation (Midgley, 2003, p. 178). In addition, the measurement of a managerial action is defined as an assignment of a certain set of values to a certain set of managerial action features (Mari, 2005). The features of a certain managerial action can be measured by a research tool which gathers data about the primal organisational term (a thing in the fundamental structure of a managerial action - Figure 1 - which means a resource in the organisational reality) (Chopraa \& Gopal, 2011).

As it is shown in Figure 2, when a team manager sets a goal (a managerial action represented by event 1.1 - set 1.1 and thing 1.1 - goal 1.1), the research tool called "Goaler" records features of goal 1.1 in time, content and human relations domains. If later (e.g. after describing a task - describe 3.1 and task 3.1) this team manager does the next 
setting of the same goal, he/she launches the next managerial action. Then the features of this managerial action are changed and represent the second version of this managerial action (setting 1.2 and goal 1.2). The difference between managerial action features of goal 1.2 and goal 1.1. allow for reasoning on the events which happened in this period of time (Flak, 2013b).

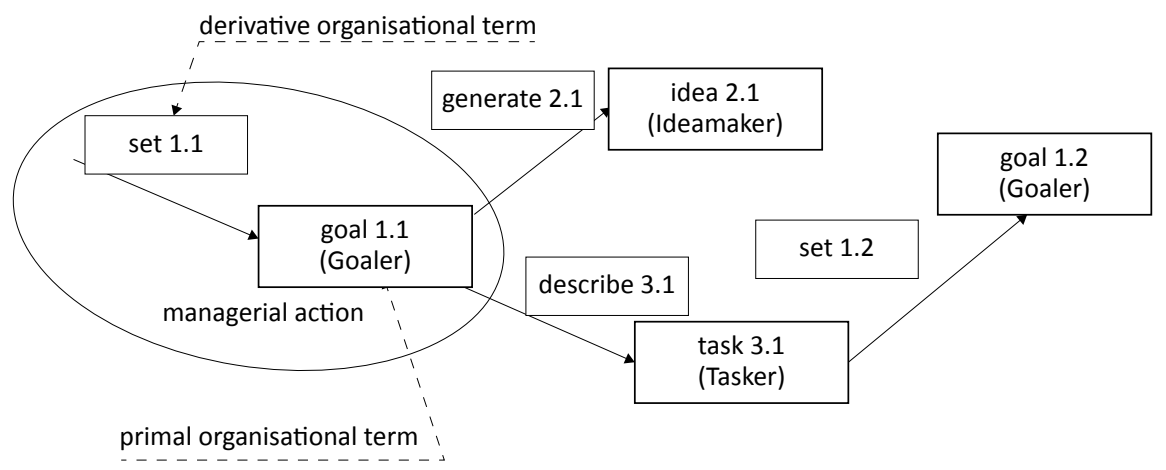

Figure 2. An example of creating resources by processes in the organisational reality

Source: own elaboration.

The research tool is in the same time the online management tool, which can be used either by team leaders in team management or by their team members.

From a theoretical point of view online management tools have features as follows. Firstly, according to the idea of a "unit of behaviour" (Curtis et al., 1992) every online management tool tracks and records one specific managerial action. Secondly, using any online management tool by a team leader is equal to an event which effects in a thing. As it is shown in Figure 1 and Figure 2, it means that it is equal to a process which results in a resource, respectively (Flak, 2013a). Thirdly, every management tool is designed for recording a certain managerial action (Flak, 2013a), especially the primal organisational term in this action.

According to the theoretical background, described above, the examples of such research tools have been created by the author of this proposed project within a project called "Pattern Recognition Techniques in Team Management Automation" funded by FoKoS ForschungsKollegSiegen - The Research Centre "Shaping the future" at the University of Siegen in 2016/2017. They were implemented 
as online management tools called TransistorsHead available on the website browser (transistorshead.com, trial - team: manager, username: manager, password: manager). This platform was designed by the author of this paper and consists of 10 different tools to track 10 separate managerial actions, e.g. setting goals, describing tasks, checking motivation, explaining problems, preparing meetings, and generating ideas. The dashboard of the management tools platform is presented in Figure 3. In Figure 3 there is a tool called SET GOALS and the goal "paper to IJCM" was created and now it has been edited.

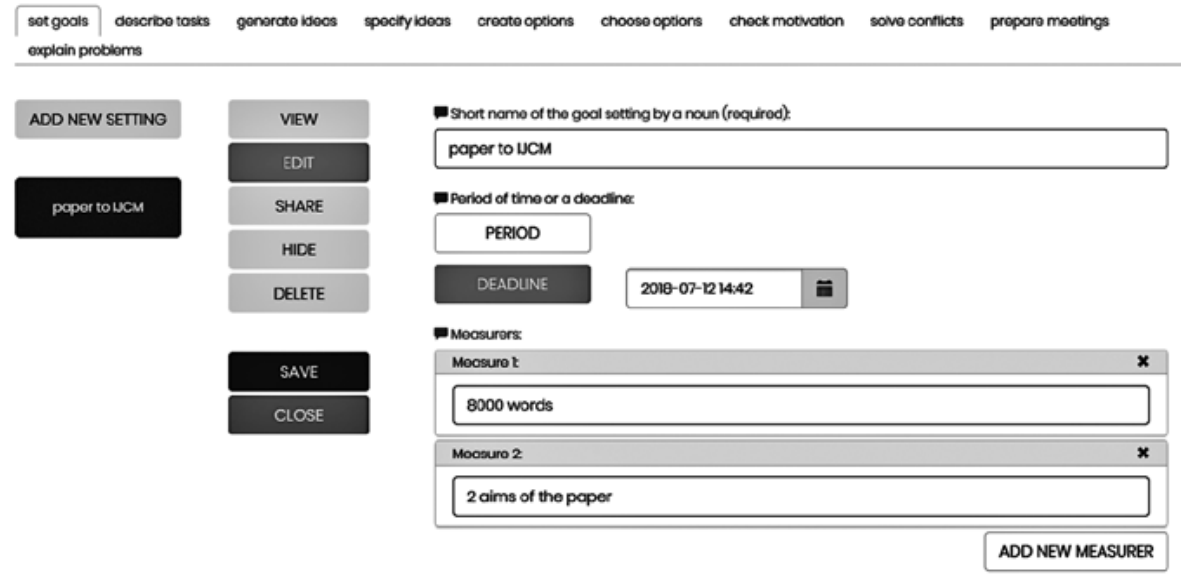

Figure 3. Goal named "paper to IJCM" being edited in the SET GOALS tool

Source: own elaboration.

In Table 1 there is a description of general functions of the online management tools embedded in TransistorsHead which were used in the virtual team research. It is necessary to claim that these 10 tools were corresponding to 10 managerial actions (with the same names) which were recorded during the observation of teamwork.

The pioneering aspect of this research method concerns the method of gathering data on team managerial actions. The data is recorded in a way, which allows for representing a team leader by managerial actions, that take place in a team, which he/she leads. That is why, the managerial actions are represented by a scalable vector. The best way of recording managerial actions by research tools is using online management tools or other electronic devices, which a team leader and his/her team members use during day-to-day work (Flak et al., 2017). The TransistorsHead platform, described above, is designed for 
Table 1. Management tools and their functions

\begin{tabular}{|c|c|}
\hline Management tool & Application of the tool during the process of teamwork \\
\hline Set goals & $\begin{array}{l}\text { Agreeing on the goals of the project, actions to be taken, etc. (what } \\
\text { is the overall goal of the project?) }\end{array}$ \\
\hline Describe tasks & $\begin{array}{l}\text { Describing tasks that will have to be performed in order to achieve } \\
\text { the overall goals }\end{array}$ \\
\hline Generate ideas & $\begin{array}{l}\text { Generating ideas (brainstorming) about performing the tasks } \\
\text { (who, how, when, where) and solving potential problems }\end{array}$ \\
\hline Specify ideas & Describing in detail the ideas and solutions \\
\hline Create options & $\begin{array}{l}\text { Creating options for decision making (deciding which options are } \\
\text { best and which options the team will choose as the final ones) }\end{array}$ \\
\hline Choose options & $\begin{array}{l}\text { Selecting and deciding which options will be chosen as the most } \\
\text { beneficial for the participants according to criteria that determine } \\
\text { this (what is the most important aspect/criterion for the team } \\
\text { leaders) }\end{array}$ \\
\hline Check motivation & $\begin{array}{l}\text { Checking the level of motivation of the team members according to } \\
\text { Maslow's theory of basic needs }\end{array}$ \\
\hline Solve conflicts & $\begin{array}{l}\text { Analysing reasons for potential conflicts among team members, } \\
\text { coming up with possible solutions of these conflicts }\end{array}$ \\
\hline Prepare meetings & $\begin{array}{l}\text { Preparing agenda for a meeting based on the law of demand and } \\
\text { supply, known in economy. The agenda allows for using the poten- } \\
\text { tial in the team and knowledge of its members }\end{array}$ \\
\hline Explain problems & $\begin{array}{l}\text { Explaining business problems or tasks by an analysis of the key- } \\
\text { words in sentences }\end{array}$ \\
\hline
\end{tabular}

Source: own elaboration.

a modern and contemporary method of time and motion study (Abbott, 1990; Barnes, 1980). This research method was tested in 2013 (Flak, 2013c; Flak \& Pyszka, 2013) and in 2015 (Flak \& Hoffmann-Burdzińska, $2015 \mathrm{a}, 2015 \mathrm{~b})$ in series of experiments with students.

\section{RESULTS OF THE RESEARCH}

\section{Observation task and conditions}

The study was attended by 41 students of Management at the University of Economics in Katowice. They were divided into 5-6 person teams as part of the subject Human Resources Management. Each team identified a team manager who led the team during the observation. The study was conducted by the means of non-participant observation. Research tools were online management tools embedded in TransistorsHead. 
Although 7 teams participated in the study, this paper describes the activity of one of them as an example. This team was chosen because of the biggest activity measured by the number of primal organisational terms that were created by the team manager and edited by the team members. The team started working on $18^{\text {th }}$ May at 10:46:38 (the first time the team manager logged in) and ended on $20^{\text {th }}$ May 2017 at 21:28:11 (logging out by the team manager). It should be stressed that the research did not include the time of completion of the task, but only the last date of handing in the work, in the form as shown in Table 2. The deadline was $2^{\text {nd }}$ June 2017 at 23:00. The observed team finished their work much ahead of time.

It should be emphasised that, from the point of view of using online management tools in TransistorsHead, which were also research tools, the team manager was able to create primal organisational terms in specific tools and share them with other team members. The team members could only edit or view the primal organisational terms (e.g. goals) created by the manager, while they were not able to create new primal organisational terms, delete, or share them.

The task of the observed teams was to prepare a training project containing 3 training programmes on 3 different subjects for the employees of the University of Silesia in Katowice. Participants in the training project had to be either administrative or academic staff. As a result of the work of the participants, a pdf containing a training project, consisting of the elements presented in Table 2, was to be produced.

Before taking on the task, the participants were trained in the online management tools implemented in TransistorsHead and were aware of recording their work history. It should be emphasised that online management tools were only used as research tools to record teamwork, and more specifically the managerial actions undertaken by team managers and team members to perform the main task. The pdf document, containing the training programme, was a separate and independent document. Participants of the observation were able to work with management tools at any time and place, so the teams formed could be treated as virtual teams, since only at the beginning and the end of the observed period the team members met in one place. 
Table 2. The contents of a training project which was to be produced

\begin{tabular}{|c|c|c|}
\hline \multicolumn{3}{|l|}{ Program element } \\
\hline \multicolumn{3}{|l|}{ Training group } \\
\hline \multicolumn{3}{|l|}{ Number of participants } \\
\hline \multicolumn{3}{|l|}{ Place of training } \\
\hline \multicolumn{3}{|l|}{ Duration of training } \\
\hline \multicolumn{3}{|l|}{ Name of training } \\
\hline \multicolumn{3}{|l|}{ Goals of training } \\
\hline \multicolumn{3}{|l|}{ Advantages for the participants } \\
\hline \multicolumn{3}{|l|}{ Training methods } \\
\hline \multirow{9}{*}{ Training modules } & 9:00 a.m. - 9:30 a.m. & \\
\hline & 9:30 a.m. - 10:30 a.m. & \\
\hline & 10:30 a.m. - 11:00 a.m. & \\
\hline & 11:00 a.m. - 12:30 p.m. & \\
\hline & 12:30 p.m. - 1:15 p.m. & \\
\hline & 1:15 p.m. $-2: 45$ p.m. & \\
\hline & 2:45 p.m. - 3:15 p.m. & \\
\hline & 3:15 p.m. $-4: 45$ p.m. & \\
\hline & 4:45 p.m. - 5:00 p.m. & \\
\hline
\end{tabular}

Source: own elaboration.

\section{General teamwork statistics}

As noted above, seven teams participated in the observation, however, due to the volume and purpose of this study, the main conclusions of the observation of the team that showed the highest activity during the study, will be presented.

The team consisted of 6 people, including the team leader and 5 members of the team. The total observation time of the team was $1,075,293$ seconds, which equals the time of observation of the team manager. This means that he logged in first and logged out as the last one in TransistorsHead. However, it should be emphasised that such long observation time (over 298 hours) does not mean that participants worked continuously on the project. As shown in Table 9 (see in the next section), some of their team activities were not recorded by the existing 10 online management tools. Other activities such as sleep, learning, work in other fields, etc. were also not been registered. However, from 
the point of view of the performance of the task and the freedom of the team members in the selection of time and place of work, these intervals should be treated as the task worktime.

In Table 3, it can be seen that only Member 3 worked on the project for almost as long as the team manager. The other team members achieved about twice as short time from the first login to the last logout from TransistorsHead.

The total number of actions undertaken in online management tools by all team members was 3,512 . However, only 1,013, i.e. about $28.84 \%$ of them, were managerial actions defined above (see Figure 1) as a set of primal organisational terms (a thing) and derivative organisational terms (an event). It should be explained why there is such a difference between these numbers. The cause is the construction of the TransistorsHead platform and online management tools, which dashboard is shown in Figure 3. Although the platform and tools were designed to maintain the maximum simplicity of use, a certain part of the actions is only switching between tools, using the manual, managing members in the team panel (this is a function only for a team leader), etc. In this way some of the actions recorded by TranisistorsHead were directly related to the use of the management tools, and not teamwork management by the leader.

It should be pointed out that taking into account only managerial actions, almost half of them were performed by the team manager. On the one hand, such a result is justified by the nature of managerial actions, but these managerial actions are not directed at the vacuum their recipients or interaction actors are the team members. In addition, the team manager could share (and did so) primal organisational terms, such as goals or tasks, which were edited by the team members. As you can see in Table 3 , the team members performed on average about $1 / 5$ managerial actions compared to the team manager. The exception is Member 4, who did most of the 167 managerial actions, despite the average working time in the project (153 hours). However, the absolute parameters describing his work (number of any actions per hour and number of managerial actions per hour) indicate his greatest activity among the team members, except the project's leader. 
Table 3. General teamwork statistics

\begin{tabular}{|c|c|c|c|c|c|c|c|c|}
\hline & & Total & Manager & Member 1 & Member 2 & Member 3 & Member 4 & Member 5 \\
\hline \multirow{5}{*}{ 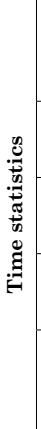 } & $\begin{array}{l}\text { Duration of teamwork } \\
\text { from the first login to } \\
\text { last logout in seconds }\end{array}$ & $1,075,293$ & $1,075,293$ & 543,489 & 458,089 & 992,215 & 551,640 & 518,744 \\
\hline & $\begin{array}{l}\text { Number of any } \\
\text { actions }\end{array}$ & 3,512 & 1,731 & 221 & 346 & 322 & 531 & 361 \\
\hline & $\begin{array}{l}\text { Number of any } \\
\text { actions per hour }\end{array}$ & 11.76 & 5.80 & 1.46 & 2.72 & 1.17 & 3.47 & 2.51 \\
\hline & $\begin{array}{l}\text { Number } \\
\text { of managerial actions }\end{array}$ & 1,032 & 496 & 79 & 93 & 98 & 167 & 99 \\
\hline & $\begin{array}{l}\text { Number } \\
\text { of managerial actions } \\
\text { per hour }\end{array}$ & 3.46 & 1.66 & 0.52 & 0.73 & 0.36 & 1.09 & 0.69 \\
\hline
\end{tabular}

Source: own elaboration.

\section{Online management tools statistics}

Table 3 shows the recorded actions and managerial actions in online management tools during the observation. As shown in Figure 3, TransistorsHead has 4 main sections: management tools (tools), archive to hide temporary useless items (archive), team management panel (team) and instruction and hints (manuals). The tools section was chosen by the participants 3,438 times, with half of the cases recorded in the entire team being chosen by the team manager. The second person in terms of activity is Member 4. The manager of the team has also selected 10 times the archive section and 6 times the team section to add - as can be assessed from the effects of their work - their team members as users of the management tools in TransistorHead and then administer their data to login.

The manager of the team has undertaken 50 managerial actions in the subtype ADD NEW, which means that it was the first managerial action of the type, e.g. he activated for the first time the managerial action of the type SET GOAL and created the item of the goal type (e.g. goal 1.1, means goal number 1 in version 1, as shown in Figure 2). None of the team members could do this, because of the design and assumptions of the TransistorsHead platform. It should be duly noted that in the final version of the recorded primal organisational terms (in the moment of the last logout of the team leader on $20^{\text {th }}$ May 2017 at 21:28:11) 47 primal organisational terms remained compared to the created 50 . This 
means that during the work time, 3 primal organisational terms were removed as e.g. unnecessary, inappropriate, or outdated.

During the team's work, the team manager edited the primal organisational terms, he had created, 274 times, although he did not always save the changes made in them. Also, Member 4 did a great job in editing primal organisational terms created by the manager - he did it 151 times. The other team members were $4-5$ times less active than the team manager. However, it is important to point out that editing a primal organisational term (which was clicking on the EDIT button in a given management tool for a given primal organisational term - see Figure 3) did not imply a change to this primal organisational term, and hence the occurrence of a new version of the primal organisational term.

For example, the team manager pressed the SAVE button 247 times, but the sum of all managerial actions in all subtypes (tool functions in Table 4) was 496 (the sum of all subtypes of managerial actions listed

Table 4. Online management tools statistics

\begin{tabular}{|c|c|c|c|c|c|c|c|c|}
\hline & & Total & $\begin{array}{c}\text { Manager } \\
\text { (leader) }\end{array}$ & Member 1 & Member 2 & Member 3 & Member 4 & Member 5 \\
\hline \multirow{4}{*}{ 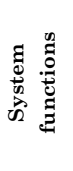 } & tools & 3,438 & 1,704 & 213 & 338 & 315 & 507 & 361 \\
\hline & archive & 10 & 7 & 1 & 0 & 0 & 1 & 1 \\
\hline & team & 6 & 3 & 0 & 1 & 0 & 1 & 1 \\
\hline & manuals & 3 & 1 & 0 & 1 & 0 & 0 & 1 \\
\hline \multirow{6}{*}{ 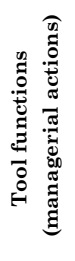 } & add new & 50 & 50 & & & & & \\
\hline & edit & 721 & 274 & 73 & 88 & 71 & 151 & 64 \\
\hline & share & 120 & 120 & & & & & \\
\hline & hide & 26 & 26 & & & & & \\
\hline & delete & 10 & 10 & & & & & \\
\hline & view & 105 & 16 & 6 & 5 & 27 & 16 & 35 \\
\hline 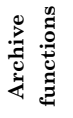 & unhide & 0 & 0 & & & & & \\
\hline \multirow{2}{*}{ 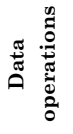 } & save & 529 & 247 & 44 & 48 & 45 & 65 & 80 \\
\hline & close & 21 & 3 & 0 & 0 & 17 & 0 & 1 \\
\hline 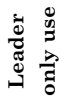 & $\begin{array}{l}\text { set } \\
\& \text { report }\end{array}$ & 144 & 144 & & & & & \\
\hline
\end{tabular}

Source: own elaboration. 
in the tool functions in Table 4). This means that in half of the cases the team manager had given up saving changes by activating only the derivative organisational term (e.g. set) but without changing the measures of the primal organisational term (in this case "goal"). Similarly, the other team members behaved like they "were going to do something", so they took a managerial action, but quit before saving their work. The most active member, i.e. Member 4 was the most inconsistent, and the most consistent turned out to be the least active, namely Member 5. The team leader also used the additional online management tool functions included in the SET \& REPORT section 144 times. He was only able to do this after being in the EDIT section (274 times), which means he used the SET \& REPORT section quite often - on average once every two edits of a primal organisational term in the management tool.

\section{Team members activities in TransistorsHead}

As mentioned above, within TransistorsHead 10 management tools were implemented, which are named in Table 5. These names also reflect the managerial actions that can be taken in a given tool and recorded by TransistorsHead. These names consist of a derivative organisational term (e.g. set) and the corresponding primal organisational term (e.g. goal). Table 5 shows the number of activities undertaken by the team manager and the team members within the TransistorsHead platform in the various online management tools. These activities are not the same as managerial actions, which are only a subset of activity. This is explained above using the example of the data from Table 3.

As one can see, the manager showed the highest level of activity, which is understandable not only because of team management, but also from the design of the online management tools - as mentioned above the team leader was the only one who was able to create items in management tools and share them with the other team members. The differences in his activity in the various tools compared to the activity of the other team members are diverse. For example, the team manager most often set goals, made options, or prepared meetings. However, the other team members were also active in creating ideas or participating in the verification of the team's level of motivation.

The most active team member again turned out to be Member 4 and the least active was Member 1 . The latter showed activity only in 5 out of 10 areas where he could use online management tools. 
Table 5. Team members activities in TransistorsHead

\begin{tabular}{|l|c|c|c|c|c|c|c|}
\hline Name of management tool & Total & $\begin{array}{c}\text { Manager } \\
\text { (leader) }\end{array}$ & Member 1 & Member 2 & Member 3 & Member 4 & Member 5 \\
\hline Set goals & 504 & 276 & 27 & 55 & 36 & 61 & 49 \\
\hline Describe tasks & 271 & 203 & 1 & 16 & 6 & 18 & 27 \\
\hline Generate ideas & 1,202 & 423 & 131 & 133 & 187 & 184 & 144 \\
\hline Specify ideas & 148 & 82 & 0 & 17 & 2 & 27 & 20 \\
\hline Create options & 206 & 132 & 0 & 23 & 1 & 45 & 5 \\
\hline Choose options & 204 & 118 & 6 & 13 & 6 & 53 & 8 \\
\hline Check motivation & 517 & 215 & 49 & 43 & 66 & 69 & 75 \\
\hline Solve conflicts & 106 & 68 & 0 & 13 & 1 & 17 & 7 \\
\hline Prepare meetings & 176 & 115 & 0 & 16 & 10 & 20 & 15 \\
\hline Explain problems & 103 & 79 & 0 & 9 & 0 & 14 & 1 \\
\hline Other & 75 & 20 & 7 & 8 & 7 & 23 & 10 \\
\hline Actions in total & 3,512 & 1,731 & 221 & 346 & 322 & 531 & 361 \\
\hline
\end{tabular}

Source: own elaboration.

\section{Primal organisational terms in teamwork}

To clarify the contents of Table 6 and Table 7, one should return to Figure 2, which shows how the next nondeterministic $\mathrm{n}$-th version of the primal organisational term is created, and how $n+1$ of this primal organisational term is created. Each primal organisational term created in the TransistorsHead managerial tools has its own unique number. If measures are changed (as a result of pressing the SAVE button), the primal organisational term is saved as its next version. At any given time, every primal organisational term created in TransistorsHead is made up of $n$ primal organisational terms, each in their i-th version.

Table 6 and Table 7 show the state for the team leader's last logout on $20^{\text {th }}$ May 2017 at 21:28:11. The number of primal organisational terms created in each of the management tools for that moment, as well as in which version each primal organisational term can be read. Table 6 and Table 7 enable drawing some conclusions.

Firstly, most primal organisational terms were created (and not removed) in the described task tools - 11 tasks. Each of them is in a version, from 1 (tasks $4,5,6,7$ ) to version 8 (task 1). This means that task 1 was changed 7 times during the work ( 8 task versions), and task 4 was not changed even once. There are 7 goals in the SET 
GOALS tool, including one for each version (except goal 3 and goal 7 both in version 2). Most often, as many as 9 times, goal 1 was changed.

Secondly, from the point of view of the end of observation, each of the management tools was used by the team manager and team members with different intensity. There were 11 tasks (describe tasks) created but only one meeting agenda (prepare meetings).

Thirdly, the number of changes made to the previously created primal organisational terms is different depending on the managerial tool, or actually on the managerial action. For example, in the case of "generate idea" the primal organisational term number 2 is at the end of the observation in its $53^{\text {rd }}$ version, and the four tasks in "describe tasks" had remained unchanged since their creation until the end of the observation.

Fourthly, for most management tools, and in fact the secondary organisational terms that are measured by them and which are part of the managerial actions, the following general relationship exists: the later the primal organisational term is created, the fewer changes are made to it. This may mean that the first notes, ideas, or thoughts are not very precise and change much during the team's work.

Table 6. Numbers and versions of primal organisational term - part 1

\begin{tabular}{|c|c|c|c|c|c|c|c|c|c|}
\hline \multicolumn{2}{|c|}{ Set goals } & \multicolumn{2}{|c|}{ Describe tasks } & \multicolumn{2}{|c|}{ Generate ideas } & \multicolumn{2}{|c|}{ Specify ideas } & \multicolumn{2}{|c|}{ Create options } \\
\hline \multicolumn{2}{|c|}{ Goals } & \multicolumn{2}{|c|}{ Tasks } & \multicolumn{2}{|c|}{ Idea } & \multicolumn{2}{|c|}{ Description } & \multicolumn{2}{|c|}{ Option } \\
\hline $\begin{array}{c}\text { Final } \\
\text { amount } \\
\text { of items }\end{array}$ & 6 & $\begin{array}{c}\text { Final } \\
\text { amount } \\
\text { of items }\end{array}$ & 6 & $\begin{array}{c}\text { Final } \\
\text { amount } \\
\text { of items }\end{array}$ & 5 & $\begin{array}{c}\text { Final } \\
\text { amount } \\
\text { of items }\end{array}$ & 2 & $\begin{array}{c}\text { Final } \\
\text { amount } \\
\text { of items }\end{array}$ & 3 \\
\hline Number & Versions & Number & Versions & Number & Versions & Number & Versions & Number & Versions \\
\hline 1 & 9 & 1 & 8 & 1 & 40 & 1 & 3 & 1 & 6 \\
\hline 2 & 5 & 2 & 4 & 2 & 53 & 2 & 4 & 2 & 7 \\
\hline 3 & 2 & 3 & 3 & 3 & 38 & & & 3 & 5 \\
\hline 4 & 3 & 4 & 1 & 4 & 28 & & & 4 & 4 \\
\hline 5 & 1 & 5 & 1 & 5 & 20 & & & & \\
\hline 6 & 4 & 6 & 1 & 6 & 27 & & & & \\
\hline 7 & 2 & 7 & 1 & & & & & & \\
\hline & & 8 & 3 & & & & & & \\
\hline & & 9 & 2 & & & & & & \\
\hline & & 10 & 3 & & & & & & \\
\hline & & 11 & 2 & & & & & & \\
\hline
\end{tabular}

Source: own elaboration. 
Table 7. Numbers and versions of primal organisational term - part 2

\begin{tabular}{|c|c|c|c|c|c|c|c|c|c|}
\hline \multicolumn{2}{|c|}{ Choose options } & \multicolumn{2}{|c|}{ Check motivation } & \multicolumn{2}{|c|}{ Solve conflicts } & \multicolumn{2}{|c|}{ Prepare meetings } & \multicolumn{2}{|c|}{ Explain problems } \\
\hline \multicolumn{2}{|c|}{ Decision } & \multicolumn{2}{|c|}{ Motivation } & \multicolumn{2}{|c|}{ Solution } & \multicolumn{2}{|c|}{ Preparation } & \multicolumn{2}{|c|}{ Explanation } \\
\hline $\begin{array}{c}\text { Final } \\
\text { amount } \\
\text { of items }\end{array}$ & 2 & $\begin{array}{c}\text { Final } \\
\text { amount } \\
\text { of items }\end{array}$ & 7 & $\begin{array}{c}\text { Final } \\
\text { amount } \\
\text { of items }\end{array}$ & 1 & $\begin{array}{c}\text { Final } \\
\text { amount } \\
\text { of items }\end{array}$ & 1 & $\begin{array}{c}\text { Final } \\
\text { amount } \\
\text { of items }\end{array}$ & 2 \\
\hline Number & Versions & Number & Versions & Number & Versions & Number & versions & Number & Versions \\
\hline 1 & 6 & 1 & 17 & 1 & 2 & 1 & 22 & 1 & 1 \\
\hline 2 & 9 & 2 & 15 & 2 & 5 & & & 2 & 1 \\
\hline 3 & 6 & 3 & 28 & & & & & 3 & 3 \\
\hline & & 4 & 9 & & & & & & \\
\hline & & 5 & 9 & & & & & & \\
\hline & & 6 & 11 & & & & & & \\
\hline & & 7 & 9 & & & & & & \\
\hline & & 8 & 1 & & & & & & \\
\hline
\end{tabular}

Source: own elaboration.

\section{Managerial actions of the team manager}

Table 8 shows the statistics of the team manager for each TransistorsHead management tool. The SAVE column relates to the confirmation of one of the subtypes of managerial actions (ADD NEW, EDIT, SHARE) undertaken in individual management tools. For example, the team manager initiated 8 times a managerial action called SET GOALS (creating a derivative organisational term called goal), 36 times he edited the goals that had been created earlier and 37 times he attempted to make them available to other team members. However, only 37 times he hit the SAVE button, which means that over half of those managerial actions did not end up creating a new version of the goal. In other words, the manager showed a certain intention, but it was not supported by real action or at the end of the action with any effect.

It should be noted once again that the number of all of the initiated managerial actions taken by the team manager during the training project was 50, but Table 6 and Table 7 show that the final team's work at the end of the observation only contained 47 primal organisational terms. This means that 3 of them were removed by the team manager. There were more attempts to remove primal organisational terms - in the "delete" column of Table 8 there is a total of 10 such actions - but some were not confirmed. In other words, it was only an intentional and not an actual action. 
One may also notice that the team manager rarely used the VIEW function in the tool (which was also a subtype of each type of managerial action). Subtype EDIT was used as many as 274 times, and the subtype VIEW only 16.

Table 8. Managerial actions of the team manager

\begin{tabular}{|l|c|c|c|c|c|c|c|}
\hline & \multicolumn{2}{|c|}{ Subtypes of managerial actions } & & \multicolumn{2}{c|}{ Subtypes of managerial actions } \\
\hline $\begin{array}{l}\text { Name of management } \\
\text { tool }\end{array}$ & Add new & Edit & Share & Save & Hide & Delete & View \\
\hline Set goals & 8 & 36 & 37 & 37 & 4 & 0 & 2 \\
\hline Describe tasks & 11 & 33 & 18 & 38 & 4 & 6 & 0 \\
\hline Generate ideas & 6 & 89 & 14 & 49 & 4 & 0 & 3 \\
\hline Specify ideas & 3 & 11 & 9 & 9 & 0 & 0 & 0 \\
\hline Create options & 4 & 17 & 8 & 22 & 2 & 2 & 2 \\
\hline Choose options & 3 & 16 & 8 & 26 & 2 & 0 & 2 \\
\hline Check motivation & 8 & 35 & 10 & 31 & 6 & 0 & 5 \\
\hline Solve conflicts & 2 & 5 & 4 & 9 & 2 & 0 & 1 \\
\hline Prepare meetings & 1 & 24 & 4 & 16 & 2 & 0 & 1 \\
\hline Explain problems & 5 & 8 & 6 & 10 & 0 & 2 & 0 \\
\hline $\begin{array}{l}\text { Subtypes of managerial } \\
\text { actions in total }\end{array}$ & 51 & 274 & 118 & 247 & 26 & 10 & 16 \\
\hline
\end{tabular}

Source: own elaboration.

Table 9 shows the team manager's behaviour based on the 16 managerial actions that were undertaken by him at the beginning of the observation. Note that in Table 9 there are rows marked "other actions not recorded", which means that in the specified intervals of time the team manager had taken other actions that were not recorded by any of the online management tools in TransistorsHead. These could be other managerial actions, for recording of which there were no management tools in TransistorsHead or other actions, not related to team management or teamwork, such as eating, making a phone call, taking a walk, etc.

From the data shown in Table 9 , it can be seen that on $18^{\text {th }}$ May 2017, 11:30:51 the manager took a managerial action type SET GOALS in subtype ADD NEW, so he set the first goal of the team which took him 211 seconds. Then TransistorsHead for almost 4 minutes did not register any team leader's action. After this time, at 11:38:20 the team manager took a managerial action type SET GOALS in the SHARE subtype, which made goal 1.1 available to his team members. 
It should be emphasised that the subtype SHARE does not change the parameters of any of the secondary organisational terms, in this case goal 1.1, so the version of this goal was not changed (still as goal 1.1).

In another 3 seconds, TransistorsHead again did not record any action taken by the team leader. At 11:38:28, there was a set of 5 managerial actions type SET GOALS in the subtype EDIT, which lasted a various number of seconds, but each time a new version of the primal organisational term was created (i.e. goal 1.2, 1.3., etc.).

At 11:49:10, a 55-second time interval had begun, when TransistorsHead did not record any managerial actions. At 11:50:05 the team leader took a managerial action type DESCRIBE TASK in subtype ADD NEW, which means that it took him 16 seconds to set up the first task for the team (the primal organisational term called task), most likely necessary to achieve goal 1.6. He then took a managerial action type CHECK MOTIVATION in subtype ADD NEW, which lasted 40 seconds. Immediately after, at 11:51:03 he again took up a managerial action type SET GOALS.

There is some explanation needed here. In Table 9, the managerial action is marked as *, because as one can read in Table 9, there is a discontinuity of numbering in the type of these managerial actions. The previous managerial action in this type was marked "set 1.7 goal 1.6", while the next one was marked "set 1.9 goal 1.8". Why such discontinuity? In the time span from 11:49:10 to 11:51:03 another team member took a managerial action type SET GOAL and did so for the primal organisational term such as goal 1.6. So in this time period a managerial action was set up which was called "set 1.8 goal 1.7", but it was undertaken by another team member, not by the team leader (as it was marked above, the team leader allowed other team members to do that at 11:38:20 using managerial action type SET GOALS subtype SHARE).

As one can see from this example, the teamwork went in parallel, and online management tools in TransistorsHead recorded this work continuously. In a similar way, you could analyse the work of other team members and their cooperation.

A sample image of the work of team manager in Table 9 ends a managerial action undertaken on $18^{\text {th }}$ May at 12:00:21 in the SET GOALS type in subtype ADD NEW, named "set 2.1 goal 2.1". This means that the team manager added a new goal, this time goal 2.1, and it took him 32 seconds. It should be emphasised that the team 
leader's work includes 496 managerial actions (Table 3), and Table 9 shows the time sequence of only 16 of them. However, on the basis of such a small portion of recorded data, online management tools in TransistorsHead can give you detailed knowledge of the workflow of the team manager and his team.

Table 9. An example of the team manager's workflow

\begin{tabular}{|c|c|c|c|c|c|}
\hline \multicolumn{2}{|c|}{ Managerial action } & Subtype & Start & End & Duration in seconds \\
\hline set 1.1 & goal 1.1 & add new & 18.05.2017 11:30:51 & 18.05.2017 11:34:22 & 211 \\
\hline \multicolumn{3}{|c|}{ other actions not recorded } & 18.05.2017 11:34:22 & 18.05.2017 11:38:20 & 238 \\
\hline set 1.2 & goal 1.1 & share & 18.05.2017 11:38:20 & 18.05.2017 11:38:25 & 5 \\
\hline \multicolumn{3}{|c|}{ other actions not recorded } & 18.05.2017 11:38:25 & 18.05.2017 11:38:28 & 3 \\
\hline set 1.3 & goal 1.2 & edit & 18.05.2017 11:38:28 & 18.05.2017 11:40:09 & 101 \\
\hline set 1.4 & goal 1.3 & edit & 18.05.2017 11:40:09 & 18.05.2017 11:45:30 & 321 \\
\hline set 1.5 & goal 1.4 & edit & 18.05.2017 11:45:30 & 18.05.2017 11:46:01 & 31 \\
\hline set 1.6 & goal 1.5 & edit & 18.05.2017 11:46:01 & 18.05.2017 11:47:35 & 94 \\
\hline set 1.7 & goal 1.6 & edit & 18.05.2017 11:47:35 & 18.05.2017 11:49:10 & 95 \\
\hline \multicolumn{3}{|c|}{ other actions not recorded } & 18.05.2017 11:49:10 & 18.05.2017 11:50:05 & 55 \\
\hline describe 1.1 & task 1.1 & add new & 18.05.2017 11:50:05 & 18.05.2017 11:50:21 & 16 \\
\hline check 1.1 & motivation 1.1 & add new & 18.05.2017 11:50:21 & 18.05.2017 11:51:01 & 40 \\
\hline set $1.9^{*}$ & goal $1.8^{*}$ & edit & 18.05.2017 11:51:03 & 18.05.2017 11:51:13 & 10 \\
\hline \multicolumn{3}{|c|}{ other actions not recorded } & 18.05.2017 11:51:13 & 18.05.2017 11:52:27 & 14 \\
\hline check 1.2 & motivation 1.2 & edit & 18.05.2017 11:52:27 & 18.05.2017 11:55:22 & 175 \\
\hline \multicolumn{3}{|c|}{ other actions not recorded } & 18.05.2017 11:55:22 & 18.05.2017 11:55:50 & 28 \\
\hline check 1.3 & motivation 1.2 & share & 18.05.2017 11:55:50 & 18.05.2017 11:55:54 & 4 \\
\hline \multicolumn{3}{|c|}{ other actions not recorded } & 18.05.2017 11:55:54 & 18.05.2017 11:56:41 & 47 \\
\hline check 1.4 & motivation 1.3 & edit & 18.05.2017 11:56:41 & 18.05.2017 11:56:52 & 11 \\
\hline \multicolumn{3}{|c|}{ other actions not recorded } & 18.05.2017 11:56:52 & 18.05.2017 11:57:51 & 59 \\
\hline check 1.5 & motivation 1.3 & view & 18.05.2017 11:57:51 & 18.05 .2017 11:57:53 & 2 \\
\hline check 1.6 & motivation 1.4 & edit & 18.05.2017 11:57:53 & 18.05.2017 12:00:17 & 144 \\
\hline \multicolumn{3}{|c|}{ other actions not recorded } & 18.05.2017 12:00:17 & 18.05.2017 12:00:21 & 4 \\
\hline set 2.1 & goal 2.1 & add new & 18.05.2017 12:00:21 & 18.05.2017 12:00:53 & 32 \\
\hline
\end{tabular}

Source: own elaboration. 


\section{CONCLUSIONS}

The presented research method of teamwork consists of (1) a stable system of terms based on ontological and epistemological assumptions which is the system of the organisational terms and (2) the online management tools used as research tools. It can be a great contribution to management sciences by recording data in long-term, non-participating observations of work. It seems there are three areas of contribution of this research method in management sciences and team management in companies.

Firstly, in the perspective of methodological problems in answering the research questions mentioned in the Introduction, this research method can overcome the domination of the study of organisational reality based on the situation at certain times. It also reduces the high influence of the researchers on the research results. In addition, the system of organisational terms shortens the disproportion in terms of ontological assumptions, methods of conducting research, and interpretation of their results.

Secondly, the system of organisational terms, embedded with online management tools as research tools, enables making a step towards pattern recognition in management in three areas (Flak et al., 2017):

- comparing managerial actions of a single manager in real time,

- comparing managerial actions of several managers one to another after their work,

- finding regularities in managers' work in defined situations.

Thirdly, the proposed research method also creates the first step to design several applications for the business practice. For example, the team management similarity and regularity is a usual and practical problem in big companies where the managers, i.e. team leaders or project managers, should work with external or internal customers delivering them specified results. Especially big companies put a lot of effort to standardise employees' work and their results. That is why the presented team manager representation and matching methods let establish a level of similarity between managers at similar positions in the company. The next application concerns the hiring process to any organisation. If the candidate could work for some time with online management tools (such as those described above and shown 
in Figure 3), there would be an opportunity to assess how much their style of management fits to the requirements at the vacated positions.

Finally, the long-term aim of this approach to research on team work is to build knowledge about managers and their subordinates' behaviour and use pattern recognition techniques in order to replace human managers with robots. This would be the real accomplishment of Drucker's words that in the future "computers" will not only make decisions but they will do much more (Drucker, 1967).

\section{REFERENCES}

Abbott, A. (1990). A primer on sequence methods. Organization Science, 1(4), 375-392. Antoszkiewicz, J.D. (1997). Firma wobec zagrożeń. Identyfikacja problemów. Warszawa: Poltex.

Backlund, A. (2000). The definition of system. Kybernetes, 29(4), 444-451.

Barnes, R.M. (1980). Motion and Time Study: Design and Measurement of Work. $7^{\text {th }}$ ed., New York: John Wiley.

Barney, J.B. (1991). Firm resources and sustained competitive advantage. Journal of Management, 17(1), 99-120.

Brink, C. \& Rewitzky, I. (2002). Three dual ontologies. Journal of Philosophical Logic, 31(6), 543-568.

Bryman, A. (2006). Integrating quantitative and qualitative research: How is it done? Qualitative Research, 6, 97-113.

Chopraa, P.K. \& Gopal, K.K. (2011). On the science of management with measurement. Total Quality Management, 22(1), 63-81.

Curtis, B., Kellner, M., \& Over, J. (1992). Process modelling. Communications of the ACM, 35(9), 75-90.

Drucker, P.F. (1967). The manager and the moron. McKinsey Quarterly, 12, http:// www.mckinsey.com/business-functions/organization/our-insights/the-manager-and-the-moron (accessed: $20^{\text {th }}$ Sept 2017).

Flak, O. (2007). Układ wielkości organizacyjnych jako obiekt badań. In: A. Nalepka (ed.), Organizacje komercyjne i niekomercyjne wobec wzmożonej konkurencji oraz wzrastajacych wymagań konsumentów [Materiały VI Seminarium Młodych Pracowników Nauki, Doktorantów i Adiunktów, 18-19.06.2007, Ząb] (pp. 64-74), Nowy Sącz: Wyższa Szkoła Biznesu.

Flak, O. (2008). Konceptualizacja układu wielkości organizacyjnych. In: A. Nalepka (ed.), Organizacje komercyjne i niekomercyjne wobec wzmożonej konkurencji oraz wzrastajacych wymagań konsumentów [Materiały VII Seminarium 
Młodych Pracowników Nauki, Doktorantów i Adiunktów, 16-17.06.208, Niedzica] (pp. 13-22), Nowy Sącz: Wyższa Szkoła Biznesu.

Flak, O. (2010). Wymiary i wielkości mierzone w układzie wielkości organizacyjnych. In: A. Nalepka, A. Ujwary-Gil (eds.), Organizacje komercyjne i niekomercyjne wobec wzmożonej konkurencji oraz wzrastajacych wymagań konsumentów [Materiały IX Seminarium Młodych Pracowników Nauki, Doktorantów i Adiunktów, 21-22.06.2010, Lipnica Górna] (pp. 11-21). Nowy Sącz: Wyższa Szkoła Biznesu - National-Louis University.

Flak, O. (2013a). Concept of managerial tools based on the system of organizational terms. In: R. Knosala (ed.), Innovation in Management and Production Engineering (pp. 187-197), Opole: Oficyna Wydawnicza Polskiego Towarzystwa Zarządzania Produkcja.

Flak, O. (2013b). Theoretical foundation for managers' behavior analysis by graphbased pattern matching. International Journal of Contemporary Management, 12(4), 110-123.

Flak, O. (2013c). Results of observations of managers based on the system of organizational terms. In: A. Nalepka, A. Ujwary-Gil (eds.), Business and Non-profit Organizations Facing Increased Competition and Growing Customers' Demands (pp. 89-102), Nowy Sącz: Wyższa Szkoła Biznesu National-Louis University.

Flak, O. \& Hoffmann-Burdzińska, K. (2015a). Management techniques and tools in project planning - part 1: Quantitative results of research. In: R. Knosala (ed.), Innovation in Management and Production Engineering (pp. 277-287), Opole: Oficyna Wydawnicza Polskiego Towarzystwa Zarządzania Produkcja.

Flak, O. \& Hoffmann-Burdzińska, K. (2015b). Management techniques and tools in project planning - part 2: Qualitative results of research. In: R. Knosala (ed.), Innovation in Management and Production Engineering (pp. 288-298), Opole: Oficyna Wydawnicza Polskiego Towarzystwa Zarządzania Produkcja.

Flak, O. \& Pyszka, A. (2013). Differences in perception of the participants in the management process and its real trajectory. Journal of Entrepreneurship, Management and Innovations, 4, 35-72.

Flak, O., Yang, C., \& Grzegorzek, M. (2017). Action sequence matching of team managers. In: M. De Marsico, G. Sanniti di Baja, \& A. Fred (eds.), ICPRAM 2017: Proceedings of the $6^{\text {th }}$ International Conference on Pattern Recognition Applications and Methods: February 24-26, 2017, Porto, Portugal (pp. 386-393), [s.l.]: Scitepress.

Goodman, N. (1997). Wstep do socjologii, transl. J. Polak, J. Ruszkowski, U. Zielińska. Poznań: Zysk i S-ka Wydawnictwo. 
Grajewski, P. (2017). Organizacja procesowa, Warszawa: Polskie Wydawnictwo Ekonomiczne.

Grygianiec, M. (2011). Trwanie w czasie. In: S.T. Kołodziejczyk (ed.), Przewodnik po metafizyce (pp. 211-276), Kraków: Wydawnictwo WAM.

Holmwood, J. (2005). Functionalism and its critics. In: A. Harrington (ed.), Modern Social Theory: An Introduction (pp. 87-109). Oxford: Oxford University Press.

Iorioa, J. \& Taylorb, J.E. (2015). Precursors to engaged leaders in virtual project teams. International Journal of Project Management, 33(2), 395-405.

Krzyżanowski, L. (1985). Podstawy nauk o organizacji i zarzadzaniu. Warszawa: PWN.

Liao, C. (2017). Leadership in virtual teams: A multilevel perspective. Human Resource Management Review, 27(4), 648-659.

Mari, L. (2005). The problem of foundations of measurement. Measurement, 38(4), 259-266.

Mathieu, J., Maynard, M.T., Rapp, T., \& Gilson, L. (2008). Team effectiveness 1997-2007: A review of recent advancements and a glimpse into the future. Journal of Management, 34, 410-476.

Midgley, G. (2003). Science as systemic intervention: Some implications of systems thinking and complexity for the philosophy of science. Systemic Practice and Action Research, 16(2), 77-97.

Olechnicki, K. \& Załęcki, P. (1998). Słownik socjologiczny. Toruń: Wydawnictwo Graffiti BC.

Rios, D. (2013). Models and modeling in the social sciences. Perspectives on Science, 21(2), 221-225.

Rokita, J. (2010). Systemowe podejście do badań nad zachowaniami organizacji. In: H. Jagoda, J. Lichtarski (eds.), Kierunki i dylematy rozwoju nauki i praktyki zarzadzania przedsiębiorstwem (pp. 258-262). Wrocław: Wydawnictwo Uniwersytetu Ekonomicznego.

Segal, S. (2011). A Heideggerian perspective on the relationship between Mintzberg's distinction between engaged and disconnected management: The role of uncertainty in management. Journal of Business Ethics, 103, 469-483.

Shakshuki, E., Ghenniwa, H., \& Kamel, M. (2003). An architecture for cooperative information systems. Knowledge-Based Systems, 16(1), 17-27.

Sinar, E. \& Paese, M. (2016). The new leader profile. Training Magazine, 46, 46-50.

Sohmen, V.S. (2013). Leadership and teamwork: Two sides of the same coin. Journal of Information Technology and Economic Development, 4(2), 1-18.

Stoner, J.A.F. \& Wankel, C. (1994). Kierowanie, transl. A. Ehrlich. Warszawa: Polskie Wydawnictwo Ekonomiczne.

Sudoł, S. (2010). Main dilemmas of management science. Organization and Management, 1(139), 8-9. 
Sułkowski, Ł. (2004). Problem niewspółmierności koncepcji w zarządzaniu. Przegląd Organizacji, 4, 6-8.

Sztompka, P. (2005). Socjologia. Kraków: Wydawnictwo Znak.

Watson, T.J. (1994). In Search of Management: Culture, Chaos and Control in Managerial Work. London: Routledge.

Zalabardo, J. (2015). Representation and Reality in Wittgenstein's Tractatus. Oxford: Oxford University Press.

Zieleniewski, K. (1965). Organizacja zespołów ludzkich. Warszawa: PWN. 


\section{METODA BADANIA PRACY ZESPOKU WYKORZYSTUJĄCA UKŁAD WIELKOŚCI ORGANIZACYJNYCH I NARZĘDZIA MENEDŻERSKIE ONLINE}

\section{Abstrakt}

Tło badań: W związku ze wzrostem złożoności i dynamizmu otoczenia organizacji coraz większego znaczenia nabiera praca zespołowa. Aby jednak była ona efektywna, a zespół osiagał zamierzone cele, muszą istnieć możliwości określania kluczowych aktywności menedżera zespołu oraz jego członków. Niestety obecne metody badawcze w naukach o zarządzaniu nie daja możliwości wyciąnięcia w pełni obiektywnych wniosków i uzyskania precyzyjnych odpowiedzi na pytania badawcze dotyczące pracy zespołowej.

Cele badań. Cele artykułu to (1) przedstawienie autorskiej metody badania zarzadzania zespołem i pracy członków zespołu na podstawie koncepcji metodologicznej układu wielkości organizacyjnych oraz (2) zaprezentowanie części wyników obserwacji nieuczestniczącej z wykorzystaniem narzędzi menedżerskich online jako narzędzi badawczych w zakresie pracy zespołowej.

Metodologia. W procesie konstruowania koncepcji metodologicznej, jaką jest układ wielkości organizacyjnych, wykorzystano obszerna literaturę przedmiotu z zakresu nauk o zarządzaniu, filozofii, logiki i informatyki. Obserwacja nieuczestnicząca została przeprowadzona z udziałem 41 studentów zarządzania, mających przygotować zadany projekt podczas pracy zespołowej. W ten sposób uzyskano dane weryfikujące przydatność prezentowanej metody badawczej.

Kluczowe wnioski. Prezentowana metoda badawcza pozwala w pewnym stopniu na rozwiązanie problemów metodologicznych w naukach o zarządzaniu w zakresie badania pracy zespołowej, a także stanowi krok w kierunku ustalania wzorców pracy menedżerów zespołów.

Słowa kluczowe: zarządzanie zespołem, metoda badawcza, układ wielkości organizacyjnych. 